\title{
Соціально-філософрські та етичні аспекти конфлікту і агресивності у спортивній діяльності
}

\author{
Олена Орленко \\ Юлія Семенова \\ Світлана Червона \\ Наталія Салтан
}

Харківська державна академія фрізичної культури, Харків, Україна

Мета: розв'язання протиріч інтерпретації спорту як чинника ствердження агресивних моделей поведінки і світоглядних орієнтацій у буденному дискурсі.

Матеріал і методи: звертаючись до результатів фрілософських, психологічних та інших наукових досліджень 3 питань агресії, конфрліктності, змагальної природи спорту здійснено аналіз перспективи розвитку етичних принципів спорту як соціального інституту.

Результати: залучення індивідуума до спортивної діяльності є стратегією мінімізації агресивності особистості в соціумі: долучаючись до спорту, людина формує звичку дотримуватись правил і спортивної етики, що вона потім буде екстраполювати на реальне життя; у процесі спортивної діяльності людина переживає низку актів психоемоційного переживання, яке долається протягом тренування; командна природа спорту мінімізує загрози утвердження егоїстичних світоглядних орієнтацій, формуючи навички перебування в колективі, i розбудови продуктивної комунікації; якісно організована спортивна діяльність допомагає системному підвищенню результатів $і$ досягнень, забезпечуючи позитивний психологічний клімат.

Висновки: фракт залучення до спортивної діяльності фрундаментальним чином трансформує світоглядні і психологічні атрибути особистості, проте, прояви агресивності носять більще ситуативний характер, аніж постають системною рисою особистості спортсмена.

Ключові слова: агресивність; конфрлікт; протистояння в спортивній діяльності; етичні принципи сучасного спорту.

\section{Вступ}

В науковій та особливо в публіцистичній літератур нерідко робляться висновки, що спорт формує агресивн тенденції, що спорт є умовою реалізації агресивних тенденцій як спортсменів, так і тих, хто спостерігає за спортивними поєдинками.

Кореляція між френоменом агресивності і спортивною діяльністю $\epsilon$, якщо не безпосередньою, то однією із важливих сюжетних ліній дослідження психологічних особливостей спортивної діяльності. 3 огляду на це, показовою виглядає теза Дж. Рассела щодо ролі конфліктів агресивності як детермінант спортивної діяльності: «Хоча найкраща моральна інтерпретація спорту може полягати в тому, щоб описати його як взаємоприйнятне прагнення до досконалості через виклик, вона дозволяє описати характер спорту як певного типу протистояння - свого роду ритуалізований фрізичний конфлікт. Бажання «домінувати», «розчавити», «покарати», «зруйнувати», «сплюндрувати», «продемонструвати відсутність милосердя» - це знайом мотиваційні інструменти, що використовуються гравцями тренерами для підвищення продуктивності. Усі такі мотиви - і вони абсолютно звичайні в спорті - мають свій початок у людському конфлікті» [5].

Метою даної статті $€$ спроба розв'язання протиріч інтерпретації спорту як чинника ствердження агресивних моделей поведінки і світоглядних орієнтацій у буденному дискурсі.

\section{Результати дослідження}

Намагаючись 3 фрілософьького погляду осягнути більше психологічну проблему агресії в спорті, хотілося б нагадати закладений історично один із ключових принципів спорту - прагнення до перемоги, що випливає із змагальної природи спорту. Водночас, в психологічній літературі й у дослідженнях в галузі фрілософії спорту майже відсутні напрацювання щодо станів, які супроводжують спортсмена, що програв у боротьбі: дійсно, як дослідників, так самих спортсменів, тренерів і вболівальників переважно цікавить складна механіка підготовки до спортивних змагань, виявлення сучасної візуальної
Проте спортивне змагання завжди має переможця і того, хто програв, що, відповідно, загострює питання етичних принципів сучасного спорту. Хто ж він - той, хто програв, з погляду психології? Людина-спортсмен за один день може перетворитись із кумира мільйонів на об'єкт ненависті чи зневаги. Ми пам'ятаємо, що навіть за античних часів спортсмени, що програвали на змаганнях, повертались додому зганьбленими, потайки, аби не постати об'єктом розправи вболівальників. Використовуючи підходи гайдеггерівської онтології, цікаві тези наводить Y.Tuncel: «Зараз спорт створює можливості для атлетичного Dasein переживати смерть у формі ризиків, здійснення помилок, програшів, створює можливості для аутентичного способу буття-у- світі... Я стверджую, що прийняття ризикованих рішень у кожній змагальній грі це не одне й те саме, що ми називає- мо ризикованим спортом; немає сумнівів, існують ступені прийняття ризикованих рішень, коли під «ризиком» ми ро- зуміємо смерть атлета. У багатьох видах спорту існує ве- лика кількість травм та болючих програшів, кожен із яких може розглядатись як «маленька смерть». Таким чином, заняття спортом, особливо у його змагальній формі, є видом буття-до-смерті, через яку атлети шукають власний аутентичний шлях буття». [6, с. 415].

Для спортсмена змагальна природа спорту постає екзистенціальним напруженням ствердження власного аутентичного способу буття. Дійсно, поразка у спортивному змаганні $є$ болісною - ніхто не бере участі у змаганнях із метою програшу, проте цей екзистенційно-психологічний стан $€$ невід'ємною складовою спортивної діяльності відповідно до її призначення, тому участь у спорті завжди споріднена із жертовністю, яку уособлює переможена особа, а психологічні механізми отримання статусу переможеного, жертви також пов'язані із потенційними загрозами утвердження агресивних моделей поведінки у спортсменів. Проте для досягнення успіхів у спортивній діяльності, необхідною вимогою $є$ максимальне розкриття позитивного потенціалу фрізичних та, не менш важливо, психологічних якостей особистості. культури тощо. 


\section{СЛОБОЖАНСЬКИЙ НАУКОВО-СПОРТИВНИЙ ВІСНИК:}

\section{Матеріали XIX Міжнародної науково-практичної конференції «Фізична культура, спорт і здоров'я: стан, проблеми та перспективи»}

Якщо рівень фрізичної підготовки суб'єктів спортивної діяльності є еквівалентним, то домінуючим фрактором для спортивних звершень стає саме психологічна готовність спортсмена, його навички з управління в стресовій ситуації. На жаль, фрізична культура і спорт часто інтерпретуються з погляду домінування фрізичних факторів, а проблема психологічної підготовки набуває другорядного характеру.

Саме цим забезпечується виникнення колізій, які спортсмен не здатен розв'язати в неагресивний спосіб. Окрім заявленої вище неоднозначної ситуації із оцінкою взаємозв'язку спорту і агресії в історії фрілософії, наша наукове дослідження ініційоване потребою розв'язання протиріч інтерпретації спорту як чинника утвердження агресивних моделей поведінки і світоглядних орієнтацій у буденному дискурсі. «У суспільній свідомості завжди існувала установка про потенційну агресивність спортсменів. Засоби масової інформації моментально тиражують випадки порушення громадського порядку відомими спортсменами. На побутовому рівні агресія асоціюється 3 негативними формами поведінки, нанесенням шкоди, збитку. А щодо спорту, то робляться висновки, що спорт «формує агресивні тенденції», що спорт $є$ умовою «реалізації агресивних тенденцій» як спортсменів, так і тих, хто спостерігає за спортивними поєдинками» [3, с. 202]. Дійсно, не завжди спортивна агресія утримується в межах соціально-безпечних форм. Часто спортивні змагання породжують гострі конфллікти, починаючи 3 міжособистісного рівня закінчуючи рівнем міждержавним. Конфліктам, що виникають у сфері спорту, властиві як загальні сутнісні риси будь-якого соціального конфрлікту, так і специфрічн особливості: по-перше, спорт - це опосередковане безпосереднє психологічне та фрізичне протистояння спортсменів, жорстка конкуренція на змаганнях і в навчально-тренувальному процесі. Йому також властива екстремальність умов, що пов'язана з високими фрізичними i нервово-психологічними навантаженнями; по-друге, спорт характеризується високою руховою активністю і можливістю прояву агресії в межах правил змагань, при цьому в деяких видах спорту в умовах жорсткого фрізичного контакту. Агресія актуалізується під час конфрліктів, які виникають у специфічних ситуаціях спортивної діяльності. Які ж саме типи конфліктів властиві спортивній галузі і галуз фрізичної культури? Доцільно систематизувати можлив конфрлікти у досліджуваній галузі за чотирма типами, зокрема:

1. Конфлікти, що виникають в ситуаціях, які перешкоджають досягненню основної мети спортивно діяльності (функціонально-рольові конфлікти в умовах спортивно- ігрової діяльності і т.ін.)

2. Конфолікти, що виникають в ситуаціях, які безпосередньо чи опосередковано перешкоджають досягненню вторинної мети спільної діяльності (реалізація особистого чи профресійного потенціалу, прагнення до зростання, вдосконалення, визнання збоку колективу)

3. Конфлікти, що виникають через способи поведінки, які не відповідають очікуванням (експектаціям) членів команди (небажання принести власні інтереси в жертву командним, недобросовісне ставлення до тренувальних занять і змагань).

4. Особистісні конфлікти, що виникають як прояв несумісності, нерозуміння (відмінностей в системі цінностей, життєвих планів, інтересів).
Дійсно, спортивна і безпосередня змагальна діяльність $\epsilon$ сферою, яка носить надзвичайно напружений у психологічному плані характер. Перспектива перемоги чи поразки здатна актуалізовувати «темний бік людської природи», проте спортивне змагання постає ареною для демонстрації своїх можливостей йти до кінця, дистанціюючись як від загальнолюдських норм поведінки, так і від аксіологічних пріоритетів спортивної діяльності, яким $€$, наприклад, концепт «Fair Play» («чесна гра»). Демонстративним, з огляду на це, виглядає футбол. Зокрема, Y.Tuncel наголошує: «Ми постійно бачимо егоїстичну поведінку у футболі. Гравець, який перебуває на позиції, 3 якої неможливо забити гол, намагається все ж вдарити його, замість того, щоб передавати м'яч іншому гравцеві, який знаходиться на кращій за нього позиції для того, щоб забити гол - існує багато причин для такої поведінки. Ця первинна людська природа, у цьому випадку, будучи егоїстичною, може бути мінімізована під час тренування із досвідченим тренером. Врешті-решт, можуть бути зроблені акценти на вищій природі, здатній забезпечити згуртованість і гру в унісон з іншими майже в кожному конкретному випадку, зокрема, коли справа доходить до забиття гола, внаслідок чого той самий спортсмен грає в гармонії з іншими гравцями» [6, с. 411]. Водночас, спортивну агресію намагається «ввести в певні рамки» фрізична культура. Виховна діяльність у процесі підготовки спортсменів має бути спрямованою, не в останню чергу, на відтворення у спортсменів ефективних навичок прийняття неагресивних рішень. На ухвалення рішення i, відповідно, рівень агресивності в спортивній діяльності впливають наступні кілька фракторів: амплуа спортсмена; змагальний досвід спортсмена; фрізична підготовленість спортсмена, яка $€$ одним 3 істотних фракторів, що обумовлюють швидкість і правильність ухвалення рішення. Також важливими є: вік спортсмена, тому що молоді спортсмени, що починають, маючи більш збудливу нервову систему і невеликий досвід участі в змаганнях, перевагу віддають безпосереднім діям, залишаючи без потрібної уваги аналіз ситуації, інтелектуальну частину діяльності, проте більш досвідчені спортсмени частіше використовують фрактор часу для з'ясування ситуації, що склалася, та виявленню слабких місць супротивника; властивості нервових процесів, (на- приклад, спортсмени зі слабкою нервовою системою, як більш чутливі, швидше реагують на ситуацію, що створилася, й прогнозують події, інертним спортсменам складніше змінити намічені дії, а спортсмени 3 неврівноваженою нервовою системою більше роблять помилок, невірних дій через надмірну збудливість). Далеко не останню роль грають інтелектуальні якості: спостережливість, кмітливість, передбачення, швидкість розуму, гнучкість розуму, що $€$ важливими чинниками у швидкості й правильності прийняття рішень у спорті; вольові якості: самостійність, ініціативність, рішучість, самовладання [1, с. 20-22].

Проблема агресії в спорті набуває соціального виміру за умови використання спорту в його антигуманному вигляді - 3 метою поширення ідеологічних конструктів, утвердження політичних режимів, спекуляції на патріотичних почуттях вболівальників тощо. Можливості суб'єкта управлінської діяльності в системі спорту безпосередньо визначаються тими особливостями управління спортивною діяльністю, що існують у структурі управління суспільством. Ця проблема носить гострий характер для безпосередньої спортивної практики, яка актуалізує питання про імплементацію результатів теоретичних досліджень у процеси мінімізації агресивності як риси сучасного спорту. 3 огляду на це, неоціненним $є$ внесок таких організацій, як «Європейський рух зачесну гру» (The European Fair Play 


\section{СЛОБОЖАНСЬКИЙ НАУКОВО-СПОРТИВНИЙ ВІСНИК:}

\section{Матеріали XIX Міжнародної науково-практичної конференції «Фізична культура, спорт і здоров'я: стан, проблеми та}

Movement), які спрямовують свої зусилля саме на практичні зміни в сучасному спортивному світі, зокрема, через проведення масштабних заходів, на яких виробляються конкретні декларації в спортивній галузі, в якому беруть участь усі зацікавлені особи (stakeholders) спорту - відомі спортсмени, тренери, дослідники, представники влади (sport policymakers) тощо.

Важливим результатом діяльності цієї організації, спрямованим на практичне подолання проявів агресивності в спорті, є декларація, що постала підсумком Шостої Генеральної Асамблеї членів руху (Париж, 2001 р.), темою якої було «Насилля у спорті та суспільстві», на якій концептуальні досягнення сучасних теоретиків спорту намагались наблизити до безпосереднього впровадження у розв'язання протиріч розвитку сучасного спорту. Зокрема, була запропонована стратегія мінімізації агресивності і насилля в спорті, загальними принципами якої стали наступні тези:

1. Надзвичайно необхідним є вжиття дій, спрямованих на стримування агресії і насилля в спорті. На жаль, підхід «закон і порядок» до цієї проблеми залишається малоефективним і мало адекватним, зважаючи на непрояснений характер причин самого явища. Рекомендується здійснювати кросс-культурні дослідження в цій галузі.

2. Політика «змахування проблем під килим», пов'язана із неспортивною поведінкою на спортивному полі, не вирішує проблем, тому варто відійти від лицемірної політики в цьому плані. Рекомендується, щоб усі національні і міжнародні спортивні органи на засадах відкритості і справжньої зацікавленості намагались подолати ерозію спортивної етики.

3. Антирасистські кампанії, що проводяться різними політичними, громадянськими та спортивними інституціями, мають бути скоординованими заради свідомих змін у спорті.

4. Будь-який прояв неприпустимої поведінки, насилля, наприклад, у середовищі спортсменів, тренерів, суддів чи вболівальників, має бути неприпустимим.

5. Будь-який прояв неприпустимої поведінки, насилля, має бути покараним задля забезпечення неможливості його використання для отримання переваг як зараз, так і в майбутньому.

6. Гравці, тренери і судді мають фокусуватись на майстерності, змагальності і прагненні до досконалості, а не суто на факті перемоги. Ті, хто програють у гарно зіграному, чесному спортивному заході, мають розуміти, що цей факт є кращим, аніж перемога в погано зіграному, нечесному заході.

7. Майстер-класи, освітні заходи і зустрічі атлетів, тренерів, суддів, адміністраторів, батьків та іншихчленів суспільства, а також кампанії, що привертають увагу до проблеми агресії, мають організовувати співпрацю щодо поширення позитивних цінностей спорту і чесної гри, а також інформувати про негативний ефект неприйнятних епізодів у спорті.

8.Учасники спортивних заходів мають розглядати суперників як партнерів у забезпеченні справедливого змагання, а не як ворогів, які мають бути переможеними за будь-яких обставин.

9. Прагнення до спортивного успіху та задоволення має резонувати із потребою проведення чесних змагань.

10. Потрібна розробка відповідних концепцій неприйнятної поведінки в різних видах спорту, одним із видів якої є насильство.
11. Медіа-форуми мають бути організовані 3 метою навчання керівного складу і персоналу щодо поширення інфрормації про негативний вплив неприйнятної і агресивної поведінки як у самому спорті, так і в середовищі вболівальників.

12. Мають бути організовані зустрічі із представниками комерційних структур, громадських організацій і урядових структур задля аналізу та реформування спортивних практик, що виглядають неетичними, негуманними i репресивними.

13. Мають бути ідентифікованими спортивнісубкультури, що здійснюють неприйнятну чи насильницьку діяльність, а також вироблені механізми мінімізації такої діяльності під час проведення спортивних заходів.

14. Політика «нульової толерантності» має бути застосована до тих представників спортивної спільноти, які здійснюють неприйнятну і насильницьку активність, спрямовану на жінок і національні меншини.

15. Позитивний і здоровий концепти спортивного тіла мають пропагуватись у публічному просторі -спортивна спільнота має бути освіченою щодо загроз і зловживань, які поширюються у сучасному спортивному середовищі [4].

Пропонована концепція носить значний потенціал і має бути якомога ширше впроваджена в безпосередню спортивну практику. До того ж, зазначені механізми подолання агресивності виходять за межі суто спортивної проблематики. Ми виходимо із методологічної позиції, що спорт є відбитком процесів, які відбуваються в суспільстві загалом. Які інші суспільні френомени, спорт часто є середовищем реалізації не найкращих людських рис характеру, таких як насилля, шахрайство, дискримінація тощо. Проте дослідження негативних рис у прикладних спортивних вимірах дозволяє допомогти суспільству робити впевнені кроки на шляху розбудови принципів соціальної справедливості, толерантності та взаємоповаги в цілому. Ми погоджуємось із тезою, що імперативи чесної гри (Fair Play) вписуються в ідеї глобальної етики і визначають характер людських відносин не тільки в межах спортивної діяльності, але й у повсякденному житті: максимальне поширення принципів олімпізму і чесної гри може надати більш гуманістичного змісту процесам глобалізації ізпритаманними їм протиріччям міжкультурної взаємодії тощо.

\section{Висновки /Дискусія}

Об'єктивні підстави надають змогу стверджувати, що фракт залучення до спортивної діяльностіфрундаментальним чином трансформує світоглядні і психологічні атрибути особистості, а прояви агресивності носять більше ситуативний характер, аніж системну рису особистості спортсмена. «Ситуативні фрактори $є$ важливим чинником виникнення агресії у спортсмена. Актуальність їх подальшого вивчення обумовлюється тим, що вони стимулюють агресію не лише у осіб, схильних до такої поведінки, але й у загалом неагресивних спортсменів. Велика кількість ситуацій (особливо ті, в яких висока ймовірність залишитися анонімним чи уникнути персональної відповідальності) можуть погіршувати здатність усвідомлення самого себе і підсилювати прояви агресивності» [2, с. 82]. Отже, продуктивним з погляду мінімізації проявів агресивності у спортсменів виглядає пошук механізмів зменшення кількості і якості провокуючих детермінант (стресових ситуацій), які провокують агресивні реакції у спортсме- 


\section{СЛОБОЖАНСЬКИЙ НАУКОВО-СПОРТИВНИЙ ВІСНИК:}

\section{Матеріали XIX Міжнародної науково-практичної конференції «Фізична культура, спорт і здоров'я: стан, проблеми та перспективи»}

нів. Залучення індивідуума до спортивної діяльності є стратегією мінімізації агресивності особистості в соціумі: долучаючись до спорту, людина фрормує звичку дотримуватись правил і спортивної етики, що вона потім буде екстраполювати на реальне життя; у процесі спортивної діяльності людина переживає низку актів психоемоційного переживання, яке долається протягом тренування; командна природа спорту мінімізує загрози утвердження егоїстичних світоглядних орієнтацій, формуючи навички перебування в колективі, і розбудови продуктивної комунікації; якісно організована спортивна діяльність допомагає системному підвищенню результатів і досягнень, забезпечуючи позитивний психологічний

Конфлікт інтересів. Автори заявляють, що немає конфлікту інтересів, який може сприйматися таким, що може нанести шкоду неупередженості статті.

Список посилань

Джерела фінансування. Ця стаття не отримала фінансової підтримки від державної, громадської або комерційної організації.

1. Бабушкин Г. Д. (1996), "Психологические механизмы возникновения и формирования профессионального интереса к спортивно-педагогической деятельности", Теория и практика физической культуры, № 1, С. $20-22$.

2. Майструк В.В., Пилипко О.А., Фотуйма О.Я. (2010), "Ситуативні детермінанти прояву агресії у спортивній діяльності". Педагогіка, психологія та медико-біологічні проблеми фізичного виховання та спорту: наук. журн. Харків: ХОВНОКУ-ХДАДМ, С. 79-82 3. Сазонов В.К. (2012), "Проявления агрессии в поведении спортсменов и неспортсменов". Вестник СПбГУ, Сер. 12. Социология, № 2, C. 202-208.

4. «Declaration on Violence in Sport and Society» (The 6th General Assembly, February 3, 2001, Paris). URL: http://www.fairplayeur. com/?page_id=34 (accessed 7 January 2019)

5. Russell J.S. (2016), «Robert L. Simon on Sport, Values, and Education». Journal of the Philosophy of Sport, Vol.43, №1, pp. 51-60. 6. Tuncel Y. (2015), Defeat, Loss, Death, and Sacrifice in Sports. Journal of the Philosophy of Sport. Vol. 42, №3, pp. 409-423.

Стаття надійшла до редакції: 11.11.2019 р. Опубліковано: 30.12.2019 р.

Аннотация. Елена Орленко, Юлия Семенова, Светлана Червона, Наталья Салтан. Социально-философские и этические аспекты конфликта и агрессивности в спортивной деятельности. Цель: решение противоречий интерпретации спорта как фактора утверждения агрессивных моделей поведения и мировоззренческих ориентаций в повседневном дискурсе. Материал и методы: обращаясь к результатам философских, психологических и других научных исследований по вопросам агрессии, конфликтности, соревновательной природы спорта осуществлено анализ перспектив развития этических принципов спорта как социального института. Результаты: привлечение индивидуума к спортивной деятельности является стратегией минимизации агрессивности личности в социуме: приобщаясь к спорту, человек формирует привычку соблюдать правила и спортивной этики, которые он потом будет экстраполировать на реальную жизнь; в процессе спортивной деятельности человек переживает ряд актов психоэмоционального переживания, которое преодолевается в течение тренировки; командная природа спорта минимизирует угрозы утверждения эгоистических мировоззренческих ориентаций, фрормируя навыки пребывания в коллективе, и развития продуктивной коммуникации; качественно организована спортивная деятельность помогает системному повышению результатов и достижений, обеспечивая положительный психологический климат. Выводы: фракт привлечения к спортивной деятельности фундаментальным образом трансформирует мировоззренческие и психологические атрибуты личности, однако, проявления агрессивности носят более ситуативный характер, чем являются системной чертой личности спортсмена.

Ключевые слова: агрессивность; конфликт; противостояние в спортивной деятельности; этические принципы современного спорта.

Abstract. Olena Orlenko, Yuliia Semenova, Svetlana Chervona, Natalia Saltan. Socio-philosophical and ethical aspects of conflict and aggressiveness in sports activities. Purpose: solving the contradictions of the interpretation of sport as a factor in the adoption of aggressive behavior patterns and ideological orientations in everyday discourse. Material and methods: referring to the results of philosophical, psychological and other scientific studies on issues of aggression, conflict, the competitive nature of sports, an analysis is made of the prospects for the development of ethical principles of sports as a social institution.Results: attracting an individual to sports is a strategy to minimize the aggressiveness of a person in society: by joining a sport, a person forms a habit of observing the rules and ethics of sports, which he will then extrapolate to real life; in the process of sports, a person experiences a series of acts of psycho-emotional experience, which is overcome during training; the team nature of sport minimizes the threat of affirming selfish ideological orientations, forming skills of being in a team, and developing productive communication; a well-organized sports activity helps to systematically increase results and achievements, providing a positive psychological climate. Conclusions: the fact of engaging in sports activities fundamentally transforms the ideological and psychological attributes of personality, however, the manifestations of aggressiveness are more situational in nature than are a systemic personality trait of an athlete. Keywords: aggressiveness; conflict; confrontation in sports activities; ethical principles of modern sport.

\section{References}

1. Babushkin G.D. (1996), "Psikhologicheskie mekhanizmy vozniknoveniya i formirovaniya professionalnogo interesa k sportivnopedagogicheskoy deyatelnosti" [Psychological mechanisms of the emergence and formation of professional interest in sports and educational activities]. Teoriya i praktika fizicheskoy kultury. No 1. pp. 20-22. (in Russ.)

2. Maistruk V. V., Pylypko O. A., Fotuima O. Ya. (2010), "Sytuatyvni determinanty proiavu ahresii u sportyvnii diialnosti" [Situational determinants of aggression in sports activities]. Pedahohika, psykholohiia ta medyko-biolohichni problemy fizychnoho vykhovannia ta sportu : nauk. zhurn. Kharkiv: KhOVNOKU-KhDADM. pp. 79-82. (in Ukr.)

3. Sazonov V.K. (2012) "Proyavleniya agressii v povedenii sportsmenov i nesportsmenov" [Manifestations of aggression in the behavior of athletes and non-athletes]. Vestnik SPbGU. Ser. 12. Sotsiologiya. No 2. pp. 202-208. (in Russ.)

4. "Declaration on Violence in Sport and Society" (2001) (The 6th General Assembly, February 3, 2001, Paris). URL: http:// www.fairplayeur. com/?page_id=34 (accessed 7 June 2019).

5. Russell J. S. (2016) "Robert L. Simon on Sport, Values, and Education”. Journal of the Philosophy of Sport. Vol.43, No 1. pp. 51-60.

6. Tuncel Y. (2015) "Defeat, Loss, Death, and Sacrifice in Sports". Journal of the Philosophy of Sport. Vol. 42, No 3. pp. 409-423.

Received: 11.11.2019

Published: 30.12 .2019 


\section{Відомості про авторів / Information about the Authors}

Семенова Юлія Анатоліївна/ Semenova Yuliia/ Семенова Юлия Анатольевна, к.фрілос.н., доцент, Харківська державна академія фрізичної культури, 61058, Харків, вул. Клочківська, 99;

ORCID iD 0000-0001-6652-1659

e-mail semenova.yuliia.a.@gmail.com.

Олена Орленко/ Orlenko Olena/ Елена Орленко, к.і.н., доцент, Харківська державна академія фрізичної культури, 61058, Харків,

вул.Клочківська, 99;

ORCID iD 0000-0003-4436-487X

e-mail olena_orlenko@ukr.net

Червона Світлана Пилипівна/ Chervona Svetlana/ Червона Светлана Филипповна, Харківська державна академія фрізичної культури, 61058, Харків, вул. Клочківська, 99;

ORCID iD 0000-0001-7491-5543,

e-mail nesveta@ukr.net

Салтан Наталія Миколаївна / Saltan Natalia / Салтан Наталья Николаевна, Харківська державна академія фрізичної

культури, 61058, Харків, вул. Клочківська, 99;

ORCID iD 0000-0001-7491-5543,

e-mail N Mahiboroda@rambler.ru 